\title{
Fibroblast Growth Factor Receptor Family Isoform IIIC
}

National Cancer Institute

\section{Source}

National Cancer Institute. Fibroblast Growth Factor Receptor Family Isoform IIIc. NCI

Thesaurus. Code C121506.

An is oform of fibroblast growth factor receptor-1, -2 , or -3 , where alternative splicing leads the expression of the IIIc exon encoding the second half of the third immunog lobulin-like domain, which is located in the extracellular domain of these receptors. This variant is expressed in mesenchymal lineage cells and has differential ligand binding activity when compared to the IIIa and IIIb forms. 